Feeding high energy diets increased the daily milk yield of Damascus $(P<0.01)$ and Zaraibi does. A high energy intake only increased $(P<0.1)$ the lactation length in Damascus does and consequently increased $(\mathrm{P}<0.01)$ the total milk yield. The differences were however not significant when feeding Zaraibi does with a high energy level.

The overall results showed that the NRC (1981) energy standards could be satisfactorily practised with lactating Zaraibi does as a low productive breed. Increasing these standards by $25 \%$ could only be achieved in Damascus does which possess a high milk production potential.

A high energy intake did not affect the milk constituents except protein. It was only increased $(\mathrm{P}<.01)$ in Zaraibi does as shown by an increase $(\mathrm{P}<.05)$ in SNF. The milk composition of Damascus does did not show any significant differences by feeding high energy diets. The protein percent was 2.51 and 2.76 , respectively with low and high energy diets in Zaraibi does, while it was 3.04 and 2.93 respectively in Damascus does. The milk protein content of Damascus does was higher than that of Zaraibi does. A high milk protein content in milk has a technical importance for milk processing.

Key words : Goat, energy, milk production, Damascus, Zaraibi.

\title{
Comparative growth-performance of male goat kids and Yaez (ibex* goat) kids
}

\author{
D. RATTNER ${ }^{(1)}$, J. LANDAU ${ }^{(2)}$
}

(1) The Institute of Animal Research, Lahav, D.N. Negev 85335 (Israël). (2) Extention Service, Ministry of Agriculture, Rehovot 76262 (Israël).

The growth-performance of Yaez kids and Sinai goat kids was compared during two seasons of two years. The weight gain of the goat kids was better in the spring $[143 \mathrm{~g} / \mathrm{d}(\mathrm{n}=11$, s.d. $=9)$ vs. $114 \mathrm{~g} / \mathrm{d}(\mathrm{n}=9$, s.d. $=34), \mathrm{p}<0.05]$, whereas the Yaez kids grew better in the summer $[152 \mathrm{~g} / \mathrm{d}(\mathrm{n}=20$, s.d. $=40)$ vs. $98 \mathrm{~g} / \mathrm{d}(\mathrm{n}=8$, s.d. $=24), \mathrm{p}<0.05]$.

In a feeding experiment carried out in the summer, two pelleted concentrates of different energy concentration were fed to $\mathrm{Yaez}$ and goat kids : the metabolizable energy, crude protein and crude fiber concentrations of the high energy concentrate (HEC) and medium energy concentrate (MEC) were : $2.74 \mathrm{Mcal} / \mathrm{kg}, 16 \%, 4.5 \%$ and $2.56,16 \%, 6.1 \%$ respectively. The difference in energy was achieved by increasing the maize percentage and including $1.5 \%$ soapstock oil in the concentrate. The feed intake (experimental group average), average daily gain (individual) and feed efficiency in the Yaez kids fed HEC and MEC were $612 \mathrm{~g} / \mathrm{d}, 152 \mathrm{~g} / \mathrm{d}$ $(\mathrm{n}=11$, s.d. $=41), 4.0$ and $584 \mathrm{~g} / \mathrm{d}, 152 \mathrm{~g} / \mathrm{d}(\mathrm{n}=9$, s.d. $=38), 3.8$, and in the goat kids $682 \mathrm{~g} /$ $\mathrm{d}, 113 \mathrm{~g} / \mathrm{d}(\mathrm{n}=4$, s.d. $=33), 6.8$ and $654 \mathrm{~g} / \mathrm{d}, 92.5 \mathrm{~g} / \mathrm{d}(\mathrm{n}=4$, s.d. $=28), 7.1$, respectively. Feeding HEC did not improve the rate of growth in kids of the two breeds.

In another experiment in Yaez kids, three meals of concentrate per day vs. ad-libitum feeding were compared. The kids fed manualy were given MEC in a clean through at 6 a.m., 12 a.m. and 3 p.m., amount of feed was adjusted to be consumed in about $30^{\prime}$, at 10 a.m. about $250 \mathrm{~g} / \mathrm{kid}$ barley straw was fed. To the ad-lib group the MEC was presented in self-feeders and the same amount of barley straw was fed at the same time. The kids fed 3 meals daily consumed less feed $(584 \mathrm{~g} / \mathrm{d}$ vs. $802 \mathrm{~g} / \mathrm{d})$ and grew at a lower rate $[154 \mathrm{~g} / \mathrm{d}(\mathrm{n}=10$, s.d. $=35) \mathrm{vs.} 187 \mathrm{~g} / \mathrm{d}(\mathrm{n}=10$, s.d. $=30)$, difference not significant], but had a better feed conversion ratio (3.8 vs. 4.3).

The seasonal variation of growth-performance in goats and Yaez kids is tentatively explained by the analysis of their sexual maturation : since a slower sexual maturation rhythm is associated with the wild ibex genome, spring born Yaez kids display much less sexual activity in the summer than spring born goat kids and therefore grow better. No such behavioral difference is noted in the spring (out of the breeding season), since autumn and winter born kids of both genotype do not show excessive sexual activity at that time. It is suggested that the spring is the season when all kids grow at a rate which is the closest to their genetic potential.

Managerial conclusions can be drawn from these results : 1. Yaez kids may be slaughtered at an older age than goat kids in the summer, whereas the optimal slaughter age for both breeds may 
be similar in the spring. 2. Goat kids born in the spring ought to be castrated at the age of $2-3$ months. 3. It may be recommended that selection for growth rate should be based on data corrected for seasonal effects.

Key words : Kids, Yaez, growth.

\title{
Relative growth rate of intermuscular adipose tissue in kids of the Granadina breed
}

\author{
M. R. SANZ SAMPELAYO, F.J. MUÑOZ HERNÁNDEZ *, L. LARA, \\ Francisca GIL EXTREMERA, J. BOZA \\ Departamento de Fisiología Animal, Estación Experimental del Zaidín (C.S.I.C.), \\ 18008 Granada (Spain) \\ * From Veterinary Sciences Faculty, Austral University (Chile).
}

Two experiments were carried out with the aim of determining the particular relative growth rate of intermuscular adipose tissue in Granadina kids. The experimental period was milk feeding, from birth until 30 days of age. The animals were fed with goat milk or a milk replacer at two different levels of metabolisable energy intake. Eight animals were used in each experiment. They were 1 or 2 to 15 days old in the first experiment and up to 30 days old in the second one. Two animals were fed goat milk or a milk replacer at a rate corresponding to 1.86 or 2.48 times the level of metabolisable energy supply for maintenance $(1.86 \mathrm{M}$ or $2.48 \mathrm{M})$, i.e. $103 \mathrm{Kcal} / \mathrm{Kg}^{0.75}$ day.

A group of five animals was slaughtered at birth. The day after each experiment was finished, all experiment animals were slaughtered. The left side of each carcass was cooled at $4{ }^{\circ} \mathrm{C}$ and divided into seven cuts : leg, rib, loin, shoulder, breast, neck and tail. Each cut, except the tail, was separated by dissection into muscle, fat, bone and waste and each tissue quantity was weighed. For each kind of milk and intake level, the allometric coefficient of the intermuscular adipose tissue of the carcass and each cut was calculated according to carcass or cut weight.

The mean carcass weight of the animals slaughtered at 30 days of age was $2,850 \pm 229.3 \mathrm{~g}$. The allometric coefficients for each kind of milk and level of intake exceeded 1.0, indicating that the fat proportions increased during the period of growth. Beside the two involved variables, these values were : $1.71 \pm 0.07,1.76 \pm 0.06,1.71 \pm 0.07,1.53 \pm 0.06,1.88 \pm 0.04,1.95 \pm 0.01$ and $1.60 \pm 0.14$ for carcass, leg, rib, loin, shoulder, breast and neck, respectively. The cuts that normally showed the highest relative growth rate exhibited the most rapid development of intermuscular adipose tissue. The type of milk had no significant effect on the relative growth of the intermuscular adipose tissue. With the high level of intake $(2.48 \mathrm{M})$ the allometric coefficients were higher than those reached under the medium level $(1.86 \mathrm{M})$, being statistically different for the loin and neck $(P<0.05)$. For the leg these data were different at $P<0.10$.

The present study evidenced the effects of the type of milk and level of intake on the development of the intermuscular adipose tissue in the kid.

The intermuscular adipose tissue of Granadina kid carcass appears to have a normal relative growth similar to that of most mammals.

Key words: Adipose tissue, growth, kid, Granadina. 